\title{
Interventions, productions and collaborations: the relationship between RAI and visual artists.
}

\author{
LEUZZI, L.
}

2015

(C) Laura Leuzzi, 2015. The definitive, peer reviewed and edited version of this article is published in: Journal of Italian cinema and media studies [online], 3(1-2), pages 155-170. Available from:

https://doi.org/10.1386/jicms.3.1-2.155_1

Terms of re-use are defined on the publisher's website: https://www.intellectbooks.com/self-archiving 
Interventions, productions and collaborations: The relationship between RAl and visual artists

Laura Leuzzi, University of Dundee

\begin{abstract}
On 17 May 1952, before RAI Radiotelevisione Italiana Studios began their regular broadcast from Milan, the Spatialist painter and sculptor Lucio Fontana broadcast his own experimental 'artwork' on Italian television, beginning a fruitful relationship between RAI and visual artists. For some, it provided careers as designers and art directors, such as the painter Mario Sasso and the Arte Povera artist Pino Pascali, while for others, who were given unique access to RAl's television apparatus, it was an opportunity to explore their own artistic experimentations with an expensive and exclusive medium, such as Carlo Quartucci and Gianni Toti. RAl also hosted seminal artists' performances on-screen including John Cage and Fabio Mauri. This article, based on documents and interviews collected during the Arts and Humanities Research Council-funded project REWINDItalia, discusses these and other seminal cases as well as tracing and assessing the history of this fruitful and complex exchange between RAI and visual artists.
\end{abstract}

\title{
Keywords
}

RAI

relationship between visual artists and television

television art

video

performance art

television

television interventions

RAl's relationship with visual artists began in the early days of Italian public television - and continued through subsequent decades - leading to seminal 
experimentation and mutual cultural growth. This differed from the American and British approaches, where the relationship between artists and television may be characterized as one of opposition, either politically or aesthetically (examples include collaborations in the United States and Great Britain). ${ }^{1}$ In Italy the many different sensibilities and attitudes coexisted. This article, examines some of the collaborations between artists and RAI, and assesses them from a critical point of view. It identifies and traces different typologies, comparing them in the wider international context of artist and broadcast television collaborations. The analysis is supported by a literary review of existing critical writings, and artists' documents and interviews collected during the research project REWINDItalia. ${ }^{2}$

The first exchange between RAI and visual artists started even before regular broadcasts began in 1954. On 17 May 1952, the Italian painter, sculptor and founder of the Spatialist Movement Lucio Fontana (1899-1968) made an experimental broadcast from the RAI Studios in Milan. On the same day he coauthored and signed, with a group of fellow artists, ${ }^{3}$ the 'Manifesto del Movimento Spaziale per la Televisione'/'Television Manifesto of the Spatial Movement' (Fontana 1952). In previous manifestos, such as in the Manifiesto Blanco/White Manifesto (1946) (co-authored with fellow artists in Buenos Aires), Fontana had already expressed a growing faith in technologies, new media and, in particular, television, and anticipated some of the theoretical basis of Spatialism. This theoretical basis continued to develop in manifestos written with other intellectuals and artists after his return to Milan, including the Primo Manifesto dello Spazialismo/'First spatialist manifesto' (1947), the Secondo Manifesto dello Spazialismo/'Second spatialist manifesto' (1948) and Proposta di un regolamento del Movimento Spaziale/'Proposal of regulations of the spatialist movement' (1950) and later II Manifesto tecnico dello Spazialismo/'The technical manifesto of the spatialism' (1951) (Crispolti 1986 2006; Bordini 1995: 20-21). In Italy, this attitude towards new media, with its trust in technological progress, had already been anticipated in the spirit of Futurism, in particular by Filippo Marinetti and Pino Masnata's La Radia Manifesto (1933), in which the importance of radio and television was discussed (Birolli 2008). However, it is in the 'Manifesto del 
Movimento Spaziale per la Televisione' that these concepts are amplified and specified with enthusiastic ardour. The manifesto proclaims:

For us, television is a means in which we have been waiting to give completeness to our concepts. We are happy that this Spatial manifestation of ours is being transmitted from Italy - a manifestation destined to renew the fields of art. ${ }^{4}$

Unfortunately, only written records remain of this experimental broadcast, in which - according to historical sources - some of his 'Holes' (Concetti spaziali/Spatial Concepts) and 'luminous images in motion' appeared together with artworks by his co-signers of the Manifesto. The broadcast is said to have included, for example, Black Light - also called Wood's Light - sculptures (Crispolti et al. 2006: 1015, Volume II), considered by many to be the ancestors of Neon-Tube Minimal Sculptures. The spatial interaction of the camera with Fontana's cut canvas, making them temporarily dynamic, is not only a vanguard episode for the Italian broadcasting but also for artists' moving image work, and this television 'event' should be considered today as a significant milestone in the historical development of video art in Italy (Bordini 1995: 22-23; Celant 2008).

In the following years RAI opened its doors to many artists who found work as designers or art directors, bringing their skills, creative approach, and contributions to some of the most relevant and seminal programmes and products of Italian public television. One of the most renowned and fertile examples is Mario Sasso. ${ }^{5}$ Born in Staffolo (Ancona), he followed Armando Testa's graphic communication courses in Turin, at the Scuola di Grafica e Pubblicità. Later he moved to Rome to continue his career as a painter. In 1958 he began his collaboration at RAl when the RAI Discoteca's Director, Phidia Schiavoni, visited his studio, and in appreciation of his work, brought some of Sasso's drawings to meetings at the company. Mario Sasso was then asked to collaborate with the production team, bringing with him an artist's perspective, new ideas and approaches (Bolla and Cardini 1994: 309; Leuzzi 2011). In 1959, 
Sasso started a collaboration as an illustrator for the educational programme Telescuola/'Teleschool' (1958-1966). The following year he was asked to make the first original opening titles sequence for an Italian television programme, Non è mai troppo tardi/'It is never too late' (1960-1968/1967), in which Alberto Manzi, a teacher and a pedagogue, taught illiterate adults how to write and read. This represented a milestone in Italian television as Sasso created a format with few references, except source material produced for Radio and some television opening titles used mainly for the News and Mike Bongiorno's quiz programmes (Gazzano 1994: 115). The result was a short film sequence (filmed on a vertical table) that showed a hand writing down some letters on a notebook, followed by an animation, with letters and geometrical forms developing the title of the programme. The technique was highly cinematographic.

Lacking reference points, the artist struggled to find his voice. In the initial stages of the process he drew many sketches, until one day in Piazza Cavour, he saw a man who was writing documents for illiterates, and from this 'naïve' and neo-realistic occurrence he drew his inspiration. The artist's intention with the opening title was to allow students at home to collect the material for the 'lesson', and therefore it became a visual and aural echo of the programme. As Sasso explains, the first step of the production of this title sequence consisted in the RAl's choice of the music score: it represented his starting point in the creative process. This procedure was adopted until 1986 and it deeply influenced the creative process of the artist. These opening sequences were structured as a 'storyboard', a sequence of drawn images that could outline the story. Sasso's sequence opened Non è mai troppo tardi for all its 484 episodes (19601968/1967) and he personally assisted on the shots of each episode, as well as making all the educational visual supports and educational material used on air.

During the 1960s and later into the 1970s, Sasso conducted a double life, working as a painter and exhibiting in numerous art galleries across Italy, alongside his career as an art director at RAI. He did not view the two activities as conflicting, but more as parallel and interwoven, as the 'experiences combined perfectly' (Gazzano 1994: 116). At the time, Sasso did not judge his 
opening sequences as artworks (Leuzzi 2011). On the contrary he felt the moral and political importance of the message being broadcast to the public and tried to honour this public mission:

I had conscience and felt that I had to be a painter who was deeply involved in social problems. I knew that my work entered particularly during the Seventies - into all the homes in Italy, and that the audience was enormous. One could cause a lot of damage or provide impressive cultural references for everybody. One could show without declaring it openly the images from Futurists and Expressionists, from Informal and Pop Art, and get the people used to vanguard languages. (Gazzano 1994: 116) ${ }^{6}$

In the following years he created numerous opening sequences for RAI television programmes such as Charlie Chaplin (1974, duration: 1', 16mm, vertical machine), Scatola aperta/'Open box' (1976-1977), II pianeta Totò/'Planet Totò' (1981-1988), Storia di un italiano/'History of an Italian' (1979-1986) (Bolla and Cardini 1994: 312). During the 1970s the programme's opening titles became more and more informative following the growth and development of the journalistic programmes that required more complex opening titles and a clear design logotype (Gazzano 1994: 116). As the artist has revealed on many occasions, he was not fully conscious, at the time, that his experience as television art director was influencing his artistic practice. But as his career progressed, the exchanges between his painting practice and the television experimentation increased and interwove until the video practice became an essential part of his visual artwork. In 1980 at Ferro di Cavallo's bookshop in Rome, he created II risveglio dell'arte dalla morte/'The awakening of art from death', his first multimedia installation mixing film and painting. It represented a turning point for Sasso's practice because it showed an intersection between his two worlds that, until that time, had remained separate. 
In the early 1980s, television broadcasters adopted computer and electronic-based apparatus, and RAl's production system completely changed. On one hand, it made obsolete certain professions and older apparatuses, but on the other hand, it opened the company to new experiences and exchanges with small, independent studios and experts. As a consequence, Sasso's approach to his practice as a graphic designer also changed and deepened his experimentation with the electronic medium. He began to use the synthesizer as a tool to modify the images and Quantel's Paintbox (an advanced digital paint and graphic system used by all major broadcasters in the 1980s). Experimenting with the possibilities and features of the Paintbox, Sasso made La Gioconda Paintbox/'The Paintbox Gioconda' (1986) a piece in which he transformed the image of Leonardo's Mona Lisa, inspired by historical artistic styles from the Renaissance to the present day. The Paintbox finally allowed Sasso to paint using the electronic medium. The software's features replicated virtually the palette and brush-strokes of the artists' studio tools, and simulated the artist's hand gestures. Furthermore, La Gioconda Paintbox shows a deep connection between Sasso's painting and his art director practice with Italian and international painting. The electronic gestures become a medium to explore and understand the history of art. The video was originally exhibited at Magazzini del Sale in Venice in the 42nd Venice Biennale, which was dedicated to Art and Science and hosted a section on Computer Art and Synthetic images (Calvesi 1986: 187-205). The installation, promoted and supported by RAl and the Biennale, included a large Ampex video projector to display the work. The video was later used as the opening sequence for the RAI Uno programme 'Grandi Mostre'/'Great Exhibitions', a weekly format dedicated to art exhibits (Bolla and Cardini 1994: 313).

Subsequently, 1986 marked a further turning point for Sasso's career and his practice as he was commissioned for the opening sequence for Tg3 (RAI 3's television News) and he was given the freedom to work from his storyboard and to choose a musician (as he had already done for TG2's opening tunes in 1983; Bolla and Cardini 1994: 314). He went to London to meet Brian Eno, who he 
commissioned to write an original tune. The result is one of the most popular 1980s' Italian television News' opening titles, made with 3D animation graphics, matching Eno's spatial music score and constituting an avant-garde work in the history of Italian television. For the 3D rendering, Sasso asked an engineer, Lorenzo Pantanetti, to create customized software that took two and half months of work to make fifteen seconds of video (Leuzzi 2011). In 1986 he presented both his video work and paintings at Artarf Gallery in Jesi, and participated in some editions of the Festival di Arte Elettronica di Camerino/Camerino Electronic Arts Festival. He also participated at the SIGGRAPH (Special Interest Group on GRAPHics and Interactive Techniques) conference on computer graphics in the United States. These participations not only show how Sasso's artistic and television practices were deeply entwined during the 1980s, one influencing the other, but also how his works produced at RAI became part of the contemporary artistic panorama and debate. Following these events, Sasso made RAI 2's La Notte della Repubblica/'The night of the republic' opening titles (1989-1990; duration: 40', 3D animation graphics) using Brian Eno's musical score along with his graphic layout. The sequence shows a virtual 3D city, which recalls Sasso's interest in cityscapes and details of urban life that have been a subject of his visual research in many of his paintings since the 1970s. Analysing these events, in their progression and evolution, it becomes clear that his two visual research paths, painting and moving image, collide. The video becomes part of his artistic practice. $^{7}$

In 1990, Sasso was involved as art director in a new project: RAISat - RAl's first satellite channel, conceived and directed by Massimo Fichera (Gazzano [1995] 2013: 220), which was broadcasted until the summer of $1993 .{ }^{8}$ Even though RAISat can be considered a late addition to the scenery of satellite channels, it can, nonetheless, be viewed as a seminal experimentation for its pan-European flavour and programming and for its involvement of intellectuals. In particular, being commissioned for the new channel's graphic layout and design line, Sasso convinced the director not only to draw inspiration from visual art but also to involve artists for the broadcasts (Gazzano 1994: 120). For the test 
pattern, Sasso created some 's-shaped' sinuous lines that symmetrically formed an ellipse, accompanied by Nicola Sani's Satellite Suite - a jingle specifically composed for it. The RAISat broadcasts opened on 29 January 1990 by Footprint, a video made by Sasso with music by Nicola Sani, at the presence of the President of the State and the Authorities. Footprint was developed in just twenty days and was designed to represent both the graphic line and conceptual approach of all the broadcast programming (Gazzano 1994: 120). The sequence was inspired by Sasso's interest towards both urban landscapes and city maps and the history of twentieth-century art. Observing the satellite images of some of the most important European cities, Sasso had noticed some common features with the artworks of visual artists who lived there, as if the urban context had influenced the gesture, the use of colour and the forms of those artists. Starting from this premise, Sasso used computer graphics to underline this parallelism: the satellite caption progressed in a visual artwork (chosen by Sasso) and the spatial musical comment by Sani accentuates this process. In 1990 Footprint was awarded the Golden Nica by 'Ars Electronica' in Linz as the best work made in 3D computer animation. The title, Footprint, refers to the imprint on the earth by the coverage of the satellite signal, and he evokes in his content an approach to a pan-European spirit. Over the previous couple of years Sasso had also made the Pictogrammi series (1988-1990; Bonito Oliva and Evola 1989; Fagone 1988), dedicated to maps. Later his research on this theme was developed in his 'Cybachromes' and the following 'Scanachromes' (c. 1993), acrylic paintings on city maps (printed in cybachrome or scanachrome) inspired to Abstract Expressionism. Another series that develop the theme of the city, on video, is Videocartoline/Videopostcards that follow up this theme, where 'psychological, imaginative and perceptive space intertwine' (Ferri and Nicolini 1997).

RAISat decided to break RAl's tradition of 'Signorine Buonasera' (Misses Good Evening), the continuity female presenters who announced or introduced the scheduled programmes, and, in another series of works, Sasso provided a visual response to the gap their 'absence' left behind. He created six sequences, 
inspired from many artistic styles of the twentieth century (Futurism, Metaphysical Art, Abstraction, Conceptual Art, Trans-avant-garde, Video Art).

$\mathrm{He}$ also invited a group of media artists, all Italians except one, to make a video Countdown (a sequence of numbers from 10 to 1 in ten seconds, inspired by the sequence of frames, usually not seen by the audience, that precede a film enabling the technical operator to get the image into focus or cue the clip for transmission). These would be employed as opening titles' sequence for a series of RAISat programmes dedicated to specific forms of art or topic in the feature entitled Footprint, dedicated to experimental programmes.

In producing this Countdown series, Sasso selected a group of artists who, at various levels and with different sensibilities, had experimented with film, video, computer art and concepts of multimedia (Bolla and Cardini 1994: 319): Gianfranco Baruchello (for Film), Mario Canali (for Documentary), Ugo Nespolo (for Pop, Rock and Jazz Music), Emanuele Luzzati (for Theatre), Fabrizio Plessi (on Fiction), Enzo Cucchi (for Soap Operas), Giacomo Verde (Classis Music), Nam June Paik (for Proxima (1992), the television programme on the future of telecommunications), Luca Maria Patella (for Science), Alighiero Boetti (for the television programme Memory) and Studio Azzurro (for the programme Est Europa/East Europe). Mario Sasso himself made two videos: one for the programme on Magazines, and another on Classical Ballet, which was initially commissioned to Mario Schifano. The artists responded very differently to Sasso's temporal and thematic constraint, and presented drawn storyboards of their sequences, which were then produced by RAISat.

Gianfranco Baruchello (1924-), who had explored video and film since the 1960s, and is internationally renowned for his collage film Verifica incerta/Uncertain Verification (1964) (produced with Alberto Grifi (1938-2007)), made a Countdown on the subject of Film, where he re-interpreted more closely the old cinema-style film countdown but with his own peculiar graphic. In fact, the same miniature objects and animals that have characterized his canvas and drawings since 1962, the very elements that Italian semiologist Paolo Fabbri has defined as 'Baruglifici'/'Baruglifics', Baruchello's hieroglyphics (after Queneau's 
Miroglifici, Miro's hieroglyphics) (Fabbri 2007), populate his Countdown's snakeshaped numbers. Luca Maria Patella (1938-), an artist who began his media experimentation first with film slides and artists' film and later with video, made a countdown, entitled in his videography Vas, realized by SBP Roma (Di Marino 1994; Patella 1999: 86), a 3D animation of his famous anamorphic vases, also evoking Renaissance studies on perspective and in particular Paolo Uccello's prospective study of vase (Pen on paper Florence, Galleria degli Uffizi, Gabinetto dei Disegni). Fabrizio Plessi (1940-), who can be considered one of the pioneers of Video Art in Italy since the 1970s, used the image of a broken television monitor with a flow of liquid colour paint (green, white and red, the colours of the Italian flag) pouring from the screen. The fluid is a recurrent theme in Plessi's practice and the image evokes the relationship between mediums - the difficult relationship between art and television. Among the most interesting clips was the one from Nam June Paik (1932-2006). The Korean artist, who had never before produced a video in Italy (although there had been various projects and contacts with Italian critics and artists), sent sketches of an animated television on a paper envelope to RAI. The project was then produced at RAl under Sasso's supervision, without Paik's presence. In the author's opinion, the sequence, in its simplicity, represents very well Paik's light and irreverent attitude towards mainstream broadcasting. Unfortunately, after only three years, RAISat closed and its exceptional production and lively experimentation ended with it. Nonetheless Sasso's works and, in particular the Countdown series, continue to be shown and screened as autonomous video works.

\section{Artists at RAI: Some seminal examples}

As Sasso recalls, during the years at RAI, many artists were able to use the television apparatus to experiment in this (at the time) expensive and exclusive medium. As Sasso himself pointed out, artists were allowed to make works in RAl Studios in Rome and take them home with them. ${ }^{9}$ Among the most renowned and interesting examples of work created for television and commercials that have been rediscovered by art historians and critics in the past 
few years, are the works of the Arte Povera member Pino Pascali (1935-1968). The works form part of his complex and multimedia activity revealing relationships with his sculptures (Ferraria and Nicolini 2012). Pascali worked as assistant set designer, and later as set designer, for the variety show Biblioteca di Studio Uno/Studio Uno's library' (1964), the music contest show Scala Reale/Royal flush' (1966-67) and the variety show Napoli contro tutti/Naples against everyone' (1964). From 1958 to 1967, he was deeply involved in opening titles, film and television commercials. Among the most successful were the Caroselli $^{10}$ for Squibb's Getto (1962) and Algida (Salvador el matador del televisor/Salvador the television bull-fighter; 1962), and two film commercials for Cafffé Camerino (1962). Most of those commercial works were made in collaboration with the director and script-writer Sandro Lodolo (1929-2009) and produced by Massimo Saraceni Cinematografica, run by Massimo Saraceni and Lodolo. Pascali and Lodolo also made a series of films for the RAl's subscription campaign 'Radiotelefortuna'/'Radioteleluck' in 1964-1965, deeply inspired to Saul Bass's (1920-1996) graphic line; in 1968 they made the opening title for TV7 (1963-1977), a TG1's research programme. In 1991, at Arco di Alibert Gallery, a film was presented with some of the surviving Caroselli made by Pascali and Sandro Lodolo. This pushed the film critic Marco Giusti to search for more in RAl's archive. As he reported, he could not find much more of Pascali's productions in RAl's archive: 'only the opening titles for Incontri and some Intramezzo [sic] ${ }^{11}$ (Ferraria and Nicolini 2012: 17) and some contracts for lost films such as Napoli contro tutti, in which Pascali was probably Cesarini da Senigallia's assistant (Ferraria and Nicolini 2012: 18). Many authors, such as Giusti and Ferraria noticed that Pascali's works for the cinema were significantly more 'free', creative and complex than those for television, conditioned by the medium and the commercial aspects. Nonetheless Giusti points out their sources and inspirations for those too, and Sandro Lodolo suggests that Pascali's drawings for the commercials are significant in studying and understanding his sculptural practice (Ferraria and Nicolini 2012: 15). His Caroselli, in particular, shares the same taste for the game and ludic feature of many of his sculptures. 
Among the many artists who worked at RAl, and who significantly experimented with visual art, was the director and writer Carlo Quartucci. Since late 1960s, he collaborated on many radio and television works for RAI. La fantastica storia di Don Chisciotte della Mancia/'The fantastic story of Don Quixote of La Mancha', broadcast on RAI on 10 April 1970, was one of the first examples of Italian creative television (Fadini and Quartucci 1976: 161). Written by Roberto Lerici and Quartucci and directed by the latter, it included the scenic project by Giulio Paolini, one of the then members of Arte Povera (Leuzzi and Catricalà 2012: 531). In autumn 1972, in RAl's studios in Turin, Quartucci made Moby Dick in five episodes, widely experimenting with the electronic language (using, e.g., chroma-key and other visual layering effects). The series was broadcast on Secondo Programma - (the second RAI channel, founded in 1961, which became later Rete 2, and then RAI 2) - on 7 March 1973 at 9.30 p.m. (Leuzzi and Catricalà 2012: 534). Also in 1972 he established, with Carla Tatò (1947-), the production company 'Camion', with which he made films for RAI television such as Borgatacamion/'Slamtruck' (Quartucci, 1977), Robinson Crusoe mercante di York/Robinson Crusoe merchant of York (Quartucci, 1981) and L'ultimo spettacolo di Nora HelmerlThe Last Piece by Nora Elmer (Quartucci, 1980), in which he developed his meditation on television as medium and language. The scenography for L'ultimo spettacolo di Nora Helmer (1980) was made by Giulio Paolini, who created a set installation with a series of pictures from previous Ibsen's House of Dolls' stages and films, 'absolving to the function of "the artist as historian" and practising "a critical art", both popular terms in those years' (Cherubini 1997: 260). These seminal experiences lead Quartucci and Tatò to found, in 1981, the interdisciplinary project 'La zattera di Babele'/'Babel's float', and later the 'Giornate delle Arti di Erice'/'Erice art days', a festival in Erice (Sicily) in whose editions, electronic art was shown.

\section{Performances on television}

RAI also hosted seminal artists' performances on-screen. One of the most celebrated cases is John Cage's performances in January 1959. Cage was a 
contestant in the famous game show Lascia o Raddoppia?/'Leave it or double it?' (1955-1959), hosted by Mike Bongiorno. ${ }^{12}$ John Cage was in Italy, having been invited by Luciano Berio to RAl's Musical Phonology Centre in Milan. While he was there, Cage made: Fontana mix per nastro magnetico, Aria per voce sola/Fontana Mix for magnetic tape, Aria for solo voice, and Sound of Venice, and wrote Variation 1 and Music Walk. His participation on the television show was encouraged by Roberto Leydi and Umberto Eco (Grasso [1996] 2003: 72).

Cage introduced himself on the show as an expert of mycology and participated for five weeks. In one of the episodes Cage presented two performances as the opening of the show: Sounds of Venice and Water Walk, with a piano, two radios, a mixer, a watering can, a gong and a boiler. As the performances were not introduced by the presenter, this allowed the artist to present his work in a non-mediated way. This addresses a fundamental example of what, since 1990, have been termed 'artists' interventions' by the UK artist and researcher Stephen Partridge (TV Interventions, 1990). ${ }^{13}$ As explained by Partridge, only a few artists, such as David Hall with his famous Television Interruptions (7 TV pieces) (1971) succeeded in breaking the traditional television explanatory strategies that would not allow artists' works to be broadcast completely unmediated. The broadcasters usually tried to bring back the artist's piece to their usual broadcast modalities (Partridge 2012: 78-79). Nonetheless, Cage's performance was harshly commented upon by Bongiorno, who said that he preferred him more as an expert of mushrooms than as a musician. Cage won a considerable sum of money and, as explained by Silverman, the Italian television experience followed him back to the United States where he was invited to perform on ABC's Henry Morgan Show and CBS's l've got a secret (1952-1967) (Silverman 2010: 169-70) in a similar vein, although with much more mediation and control by $\mathrm{ABC}$ and the hosts.

Another example of what can be defined a television intervention broadcast by RAl is Fabio Mauri's II Televisione che piange/'The crying television' (1972). This work was in the form of and event or happening, proposed in a television programme entitled Happening (1972) curated by Paquito del Bosco and Enrico 
Rossetti following an historical survey of the art phenomenon of the time. The sequence is introduced by Mauri, who, facing the camera, gives an explanation of the meaning of happening: "happening" (he says the word in English) - the "avvenimento" - is usually a normal happening and because of the awareness and because of the attention applied by the artist and by the consumer, who is around the happening, it becomes exceptional. It's seen. It's stressed'. After Mauri's explanation the screen became blank white and silent and then a voiceover of a crying sound breaks the silence. On the screen appears the title of the 'intervention'. Then the camera frames the inscription 'The End' from one of Mauri's paintings. As it is explained by Dora Aceto: 'Many people phoned RAI reporting the prolonged breakdown: someone cried in the void of the screen' (Mauri 2009: 116). Regarding the symbolical meaning of the happening, she explains, 'The lament, in Mauri's intention, was political, sorrowful for daily contradictions of life in Italy' (Mauri 2009: 116). As Stephen Partridge has remarked:

Mauri's strategy is intriguing, as he employs one of the most frequent devices that the broadcaster uses - that is, an explanation through a-piece-to-camera which he uses to book-end the short 30 second section of crying and white screen, and in the process introduces and concludes his own work, thus pre-empting and defeating any effort by the broadcaster to mediate the work itself. ${ }^{14}$

In these critical observations, Partridge underlines the dramatic conflict between the artist's intervention and the broadcast's mediation: the problem that he has pointed out in many other 'artists' interventions' and that in Mauri's case was sublimated by the artist's televisual presence. Mauri's historical contextualization succeeds not only in creating a frame for the happening, but as he also explained, the television piece was nourished by, and complementary to, his painting practice. As mentioned, at the end of the happening he shows one his Schermi/Screens, a series, that he had developed between 1957 and 1960, with 
monochrome canvas and drawings, evoking cinema and television screens, on which sometimes the two words 'The end' are almost unreadable (Bakargiev and Cossu 1994).

Beyond Italy, in 1964-1965, French Radio Television Office (ORTF) had supported works by artists such as Jean Christophe Averty; and in the United States, in 1967, KQED-TV in San Francisco had developed an experimental workshop and in 1969 Boston's WGBH-TV organized a residency for artists. In the United Kingdom in 1969 John Hopkins founded TVX the first British television workshop in 1969 with Cliff Evans. In 1970 the BBC commissioned him for a series of experimental video programmes, working with broadcast video equipment given to him by John Lennon (but only two were actually broadcasted). In 1968-1969 Gerry Schum filmed, on $16 \mathrm{~mm}$, a number of works by a group of artists for his famous Land Art programme that was then broadcasted on the Berlin channel 'Freies Berlin'.

In 1971 David Hall created for Scottish Television his famous ten TV Interruptions - one of the only examples of unmediated broadcasts on mainstream television. These experiments were well known in Italy. In fact Gerry Schum was invited by Renato Barilli, Tommaso Trini and Maurizio Calvesi to show his works at the seminal exhibition 'Gennaio 70' (Barilli et al. 1970) and later at 1972 Venice Biennale. Furthermore, in 1971, Francesco Carlo Crispolti, a journalist at RAl, wrote a short piece (translated into English and French) on video tape recording for the catalogue of a video programme (VideObelisco) he was curating at Obelisco Gallery in Rome (Crispolti 1971: n.p.). In this text, Crispolti mentions the antagonistic relationship between artists and television, and he references Schum's experience in particular.

\section{RSP and Gianni Toti video poetry}

In 1968, RAl founded the 'Servizio Programmi Sperimentali' (Service for Experimental Broadcasts), which in 1976 became 'Settore Ricerca e Sperimentazioni Programmi' (RSP - Research and Experimentation Department), a department dedicated to the experimentation of televisual 
language directed by Emilio Pozzi. ${ }^{15}$ RSP was a very marginal, poorly funded department: although this singular situation gave a wide freedom to authors, the channel usually ignored their suggestions, and their productions were often never broadcast. In 1973 RSP produced a 25-minute programme, completely abstract, by the painter Eugenio Carmi (1920-), with music by Angelo Paccagnini, entitled C'era una volta un re che aveva tre figlie bellissime/'Once upon a time a king had three beautiful daughters' (Leuzzi and Catricalà 2012: 535). In 1977 the poet and journalist Gianni Toti was invited by the Cypriot author Annita Triantafyllidou to collaborate on a 25-page research paper for the RSP, entitled 'Videolettura'/'Videoreading'. During the 1960s and 1970s he had already collaborated with RAI for programmes and television series, as an actor too, but had never been specifically interested in video or television as a medium from a theoretical or practical point of view.

In their research Toti and Triantafyllidou explored theoretically the possible exchanges between prose and poetry pieces and video in order to produce 'expressions specifically televisual in the field of writing-reading' (Barenghi 2012: 144). This document, now lost, is still mentioned in RAl's archive; and later in Toti's writings and contributions, he talks about a project entitled 'Per una videolettura'/'For a videoreading', which he had presented to Pozzi in 1977. As Anna Barenghi suggests, these two projects probably coincided (Barenghi 2012: 144). The importance of this lost paper resides in the fact that it may explain the origins of Toti's interest towards video and his early theoretical and experimental interest on the subject. The following year (1978) the conference of the famous 'Prix Italia', organized by RAI, was dedicated to the relationship between artists and television. This points out the growing debate among intellectuals, producers and artists on the subject in Italy. ${ }^{16}$ Later, in March 1980, Toti made in the RAI Production Centre in Milan the recordings for his first video work Per una videopoesia. ConcerTesto e improvvisazione per mixer, memoria di quadro e oscillo-spettro-vector-scopio/'For a video poetry. ConcerText and Improvisation for mixer, frame synchronizer and oscillo-spector-vector-scope' (duration: 50'), 
which began experimentations about the incorporation of poetry and electronic medium, and which he later termed 'poetronica'.

In 1981, at the RAl Centre of Production in Milan, he made Tre videopoemettil'Three Short Videopoems: Voyelles', dedicated to a sonnet by Rimbaud; Videolettura di videopoesia su poetarchegrafial'Videoreading of videopoetry on archeopoetgraphic', dedicated to his own poetry collection Compoetibilmente infungibile/'Compoetibilly unfungible'; and lastly Nebulosa testuale/'Textual Nebula', dedicated to Mallarmé's Un coup de dés jamais n'abolira le hazard/A throw of the dice will never abolish chance' (Barenghi 2012: 147-48). In a piece that appeared on the journal Cinema 60, Toti also mentioned texts for a videopoemetto $n .5$ (Chimeraman)/'short videopoem n. 5 (Chimeraman)' and a videopoemetto $n .7$ (Ave Mixer! Monitori te salutant!)/'short videopoem n.7 (Monitori salute you!)'. Unfortunately it has not been possible to determine if those videos were completed or were just projects 'in progress'. These productions were originally thought of, by the artist, as an intervallo - a little interlude between programmes. But they were never used as such. As he explained in an interview with Anna Barenghi, Toti had expressed his intentions to RAI saying that:

Since they are short video poems, it would be interesting, in my opinion, if the audience - who always watch the television in a nonelaborate and non-serious way - could get used to watching a little brief video, of a few minutes, 2 or 3 minutes, a video that is not television. ${ }^{17}$

In these early works the artist explores the expressive possibilities of television effects and devices (split-screen, feedback, titler, vectorscope and oscilloscope), his voice-over sometimes guides the audience explaining the effects on-screen. The content of the videos also include critical points of view and opinions by Toti towards RAl and its use of the medium for the masses. From February to November 1983, Toti made three videos, all dedicated to the character of the 
ballerina interpreted by Lili Brik (1891-1978), Majakovskji's most renowned muse, in Sakovannaia Filmoi, ${ }^{18}$ later grouped and named by the artist as $\mathrm{La}$ trilogia majakovskjana/The Majakovskjan trilogy'. The first video was VALERIAscopia o dell'amMAGLlattrice/'Valeriascopy or of the charmer' in which Valeria Magli, the ballerina, appears to come out of a poster of the movie. In the second Incatenata alla pellicola ovvero Maiak (lolobrik)ovskj/Chained by the film or Maiak(lilibrik)ovskj', Toti modified the 2' 40' survived cuts from the original film, through the television medium: the cinematographic image was deformed, changed and manipulated by the electronic language (Barenghi 2012: 151). The third Cuor di Telema/Telema's Heart shot at RAl's Studios in Milan, at the National Film Museum in Turin was inspired from Majakovskij's Heart of Cinema. This cycle, as with many of Toti's works, embodies his multimedia approach. His works are full of literary and visual quotes and references to what were defined the 'ten, hundred, thousand lives' that he lived (Lischi and Moretti 2012: 12).

Unfortunately, in 1987 the RSP department was closed for a restructuring of the company, and a fundamental chapter in the history of experimental practices on the medium at RAI came to an end. Its activity was passed on to Unità Operative per i Nuovi Servizi/Operative Unit for New Services (UONS), which abandoned RSP's cutting edge approach. Toti's project, SqueeZangeZaúm, which had just been approved before RSP's closure, was abandoned. But the following year it was produced by RAITre, Istituto Luce-Italnoleggio and UONS (Barenghi 2012: 155). Later Toti produced video artworks in electronic art contexts and productions (such as CICV- Montbéliard-Belfor's Centre de Recherche Pierre Schaeffer), taking more and more distance from television productions. Thereafter RPS's history and its achievements passed progressively to oblivion.

In conclusion, RAl's attitude towards visual artists was somehow ambiguous and ambivalent. Although many artists were granted the opportunity to use RAl's apparatus with the support of operators and engineers, and were even invited to experiment on the medium, at the same time the artists' video works that were produced were rarely broadcast and almost never properly 
valued by the company. In particular the possibility of educating an audience in experimental electronic art was never truly shared. The productions were perceived just as isolated experimentations, sometimes (as in Toti's and sometimes Sasso's case) destined only to appear in festivals and exhibitions. Sasso's experimentations, on the other hand, only achieved a more true and wider freedom from the mid-1980s and always within the realm of opening titles sequences, or graphic layout in the design line of the broadcast (as in RAISat). Performers such as Cage and Mauri succeeded in creating unmediated works only partially as they were contained in larger broadcasts and were later commented, even if in Mauri's case by the artist himself. Unfortunately some of the mentioned works are not available because they have not been recovered or are considered lost. Those, which are available, are rarely or never broadcast. Nonetheless, artworks produced at RAI were and continue to be viewed, shared in media art contexts (exhibitions, screenings). The hope is that a future awareness will help re-evaluate those experiences and enable them to be considered properly.

\section{Acknowledgements}

I would like to thank Professor Stephen Partridge, Professor Marco Maria Gazzano and Dr Emile Shemilt for the support and help for this article. I am indebted to Luca Maria Patella, Rosa Foschi, Mario Sasso, Carlo Quartucci and Carla Tatò for the exchanges. I am grateful to Valentino Catricalà for the constant exchange of materials. This would have not been possible without the support of La Casa Totiana and Associazione Culturale Kinema.

\section{References}

Bakargiev, C. and Cossu, M. (eds) (1994), Fabio Mauri: opere e azioni, 19541994/Fabio Mauri: works and action, 1954-1994', Milan: G. Mondadori.

Barenghi, A. (2011), Gianni Toti e le disperimentazioni in RAl/Gianni Toti and disperimentazioni at

RAl', 
http://lacasatotiana.blogspot.ch/2011_07_01_archive.html. Accessed 2 June 2014.

(2012), 'Un (di)sperimentale alla Rai'/'A (dis)perimental at RAl', in Lischi, S. and Moretti, S. (eds), Gianni Toti o della poetronical'Gianni Toti or about poetronica', Pisa: ETS, p. 144-55

Barilli, R., Calvesi, M. and Trini, T. (1970), 3. Biennale internazionale della giovane pittura: gennaio 70 Comportamenti progetti mediazioni/Third International Biennial of young painting: January 70 . Behaviours projects mediations', Bologna: Edizioni Alfa.

Baruchello, G. and Grifi, A. (1964), Verifica incerta/Uncertain Verification, Italy.

Biblioteca di Studio Uno/Studio Uno's library' (1964, Italy: Programma Nazionale).

Birolli, V. (ed.) (2008), Manifesti del futurismo/'Futurism's manifestos', Milan: Abscondita.

Bolla, L. and Cardini, F. (eds) (1994), Le avventure dell'arte in tv: quarant'anni di esperienze italiane/'Art adventures on TV: Forty years of Italian experiences', Rome: RAI- Nuova Eri.

Bonito Oliva, A. and Evola, D. (1989), Mario Sasso. On/off: pictogrammi, videogrammi/Mario Sasso. On/off: pictograms, videograms', Rome: Carte Segrete.

Bordini, S. (ed.) (1995), Videoarte e arte/'Video art and art', Rome: Lithos. 
Cage, J., Paz, O., Martinengo, L., Verità, T. and Torrealta, L. (1978), Dopo di me il silenzio. John Cage/'After me the silence. John Cage', Milan: Emme.

Calvesi, M. (ed) (1986), 42. Esposizione internazionale d'arte La Biennale di Venezia: catalogo generale/42. International art exhibition Venice Biennale: General catalogue', Venice/Milan: La Biennale/Electa.

Carmi, E. (1973), C'era una volta un re che aveva tre figlie bellissime/'Once upon a time a king had three beautiful daughters', Italy: RAI.

Carosello (1957-1977, Italy: Programma Nazionale, Rete 1).

Celant, G. (2008), Artmix: flussi tra arte, architettura, cinema, design, moda, musica e televisione/'Artmix: Flow between art, architecture, cinema, design, fashion, music and television', Milan: Feltrinelli.

Charlie Chaplin (1974, Italy: Programma Nazionale).

Cherubini, L. (1997), 'Giulio Paolini/Spettacoli teatrali'/'Giulio Paolini/Theatre shows', in Fagiolo dell'Arco, M., Giannelli, I. (eds), Sipario. Balla, De Chirico, Savinio, Picasso, Paolini, Cucchil Sipario: Staged Art. Balla, De Chirico, Savinio, Picasso, Paolini, Cucchi, Milan: Edizioni Charta, pp. 254-65.

Crispolti, E. (1986), Fontana: catalogo generale/'Fontana: General catalogue', 2 vols, Milan: Electa.

Crispolti, E., Ardemagni Laurini, N. and Ernesti, V. (2006), Lucio Fontana: catalogo ragionato di sculture, dipinti, ambientazionil'Lucio Fontana: Catalogue raisonné of sculptures, paintings, sets', 2 vols, Milan: Skira. 
Crispolti, F. (1971), VideObelisco: Art Video Recording, AVR, Rome: Galleria dell'Obelisco.

Di Maggio, G., Bonito Oliva, A. and Lombardi, D. (eds) (2009), John Cage, Milan: Mudima.

Di Marino (1994), Luca M. Patella. Con e senza peso. Film e video/'Luca M. Patella. With and without weight. Film and video', Rome: Università degli Studi di Roma La Sapienza, Museo Laboratorio di Arte Contemporanea.

Di Marino, B. and Nicoli, L. (eds) (2001), Elettroshock. 30 anni di video in Italia, 1971-2001/'Elettroshock. 30 years of video in Italy 1971-2001', Rome: Castelvecchi.

Fabbri, P. (2007), Gianfranco Baruchello. Flussi, pieghe, pensieri in bocca/'Gianfranco Baruchello: Flow, creases, thoughts in the mouth', Milan: Skira.

Fadini, E. and Quartucci, C. (1976), Viaggio nel camion dentro l'avanguardia/'Travel on the truck inside the avant-garde', Turin: Studio Forma.

Fagone, V. (ed.) (1988), Pittogrammi videogrammi. Mario Sasso/'Pictograms videograms. Mario Sasso', Rome: Carte Segrete.

Ferri, P. and Nicolini, R. (1997), Mario Sasso. Frammenti metropolitani: opere/'Mario Sasso. Metropolitan fragments: Works', Naples: Efferre.

Ferraria, D. and Niccolini, J. (eds) (2012), Pino Pascali. L'altro Pascali. Un itinerario attraverso le opere per il cinema e la televisione/'Pino Pascali. The other Pascali. An itinerary through works for Cinema and Television', Cinisello Balsamo: Silvana. 
Filonzi, A. (ed.) (2008), Videoglaz: Mario Sasso e l'immagine elettronica/'Videoglaz: Mario Sasso and the electronic image', Rome: Edizioni Volume!.

Fontana, L. (1952), 'Manifesto del Movimento Spaziale per la Televisione'/'Television manifesto of spatial movement', in J. De Sanna (ed.) (1993), Lucio Fontana. Materia, spazio, movimento/'Lucio Fontana. Matter, space, movement', Milan: Mursia, p. 178.

Gazzano, M. M. (ed.) (1994), Mario Sasso, architetture elettroniche. La Città, la Televisione/'Mario Sasso, electronic architectures. The city, the television', exhibition catalogue, Lingotto, Turin and Rome: Sedac/Carte Segrete.

([1995] 2012), 'RaiSat. Un'esperienza di interazione tra artisti, nuove tecnologie e programmazione progettuale della televisione pubblica italiana'/'RaiSat. An experience of interaction between artists, new technologies and planning programming of the Italian public television', in M. M. Gazzano, Kinema. Il cinema sulle tracce del cinema dal film alle arti elettroniche, andata e ritorno/'Kinema. The cinema on the traces of cinema from film to electronic arts and back', Rome: Exòrma, pp. 220-42.

Grasso, A. (ed.) ([1996] 2003), Enciclopedia della televisione/'Encyclopaedia of television', 1st ed., Milan: Garzanti/Mondadori.

Hall, D. (1971), TV Interruptions (7 TV pieces), Scotland: Scottish Television.

Happening (1972, Italy: Secondo Programma).

I've got a secret (1952-1967, 1976, USA: CBS). 
II pianeta Totò/Planet Totò' (1981-1988, Italy: Rete 1-RAIUno).

La Notte della Repubblica/The night of the republic' (1989-1990, Italy: RAIDue).

Lascia o Raddoppia?/'Leave it or double it?' (1955-1959, Italy: Programma Nazionale).

Leuzzi, L. (2011), 'Interview to Mario Sasso', http://www.rewind.ac.uk/rewind/index.php/l-banca_dati. Accessed 2 June 2014.

Leuzzi, L. and Catricalà, V. (2012), 'Tabella cronologica'/'Chronological chart', in Gazzano, Kinema. Il cinema sulle tracce del cinema dal film alle arti elettroniche, andata e ritorno/'Kinema. The cinema on the traces of cinema from film to electronic arts and back', Rome: Exòrma, pp. 527-55.

Lischi, S. and Moretti, S. (eds) (2012), Gianni Toti o della poetronical'Gianni Toti or about poetronica', Pisa: ETS.

Mauri, F. (1972), II Televisione che piange/'The crying television', Italy: RAI. (2009), Io sono un ariano/'I am an Aryan', Rome: Edizioni Volume!.

Napoli contro tutti/'Naples against everyone' (1964, Italy: Programma Nazionale).

Non è mai troppo tardi'lt is never too late' (1960-1968/1967, Italy: Programma Nazionale/Secondo Programma).

Partridge, S. (2012), 'Artists' television: Interruptions-interventions', in S. Partridge and S. Cubitt (eds), REWIND| British Artists' Video in the 1970s \& 1980s, New Barnet, Herts: John Libbey, pp. 75-90. 
Partridge, S. (1990), 19:4:90: Television Interventions, London: Field and Frames Productions.

Patella, L. M. (1999), i Media (ieri e oggi). Art and Non art!l'The Media (yesterday and today). Art and not art', Rome: Museo Laboratorio di Arte Contemporanea.

Proxima (1992; Italy: RAISat)

Quartucci, C. (1970), La fantastica storia di Don Chisciotte della Mancia/'The fantastic story of Don Quixote of La Mancha', Italy: RAI.

(1972), Moby Dick, Italy: RAI.

(1977), Borgatacamion/Slamtruck', Italy: RAI.

(1980), L'ultimo spettacolo di Nora Helmerl'The last piece by Nora Helmer', Italy: RAI.

(1980), Robinson Crusoe mercante di York/Robinson Crusoe Merchant of York, Italy: RAI.

RAI/Prix Italia (1979), Atti del Convegno su Le arti visuali e il ruolo della televisione/Proceedings of the Meeting on TV and Visual Arts, Milan, 12-13 September, Turin: ERI-Edizioni RAI.

Sasso, M. (1986), La Gioconda Paintbox/'The Paintbox Gioconda', Italy: RAI.

__ (1990-1992), Countdown, Italy: RAISat. (2003), Mario Sasso: dalla pittura all'elettronica/'Mario Sasso: from painting to eletronic', Ancona. 
Sasso, M. and Sani, N. (1990), FootPrint, Italy: RAISat.

Scala reale/'Royal flush' (1966-67, Italy: Programma Nazionale).

Scatola aperta/Open box' (1976-1977, Italy: Rete 1).

Schum, G. (1968/1969), Land Art, Berlin: Fernsehgalerie.

Senaldi, M. (2009), Arte e televisione. Da Andy Warhol al Grande Fratello/'Art and television. From Andy Warhol to the Big Brother', Milan: PostmediaBooks.

Silverman, K. (2010), Begin again: A Biography of John Cage, New York: Knopf.

Storia di un italiano/'History of an Italian' (1979-1986, Italy: RAI 2).

Telescuola/'Teleschool' (1958-1966, Italy: Programma Nazionale).

Toti, G. (1980), Per una videopoesia. ConcerTesto e improvvisazione per mixer, memoria di quadro e oscillo-spettro-vector-scopio/For a video poetry. ConcerText and improvisation for mixer, frame synchronizer and oscillo-spectorvector-scope', Milan: RAI-RSP.

(1981), Tre videopoemetti|'Three Short Videopoems': Voyelles/'Vowels', Videolettura di videopoesia su poetarchegrafia/'Videoreading of videopoetry on archeopoetgraphic', Nebulosa testuale/Textual Nebula', Italy: RAI- RSP

_ (1983), La trilogia majakovskjana/The Majakovskjan Trilogy': VALERIAscopia o dell'amMAGLlattrice/'Valeriascopy or of the charmer', Incatenata alla pellicola ovvero Maiak (lolobrik)ovskj/Chained by the Film or Maiak(lilibrik)ovskj', Cuor di Telema/'Telema's Heart', Italy: RAI-RSP. 
(1988), SqueeZangeZaúm, Italy: RAI, Istituto Luce-Italnoleggio and UONS.

TV Interventions (1990, United Kingdom: Fields and Frame Productions for Channel 4).

Tv7 (1963-1977, Italy: Programma Nazionale, Rete 1)

Walker, J. A. (1993), Arts TV. A History of Arts Television in Britain, London: The Arts Council of England, John Libbey.

\section{Contributor details}

Dr Laura Leuzzi is an art historian and curator based in Rome, Italy. She is currently a Research Fellow on the AHRC-funded research project REWIND/talia, at Duncan of Jordanstone College of Art and Design, University of Dundee, Scotland. Her academic research is particularly concerned with the relationship between words and image in visual art and new media. In 2008 she curated the exhibition 'Artefacta e le Biennali del mondo' (Mestre, Centro Culturale Candiani); and in 2009 and 2010 she co-curated the cycle '(dieci luglio duemilaotto)' with Emanuele Sbardella. As a Research Fellow with REWIND/talia, she has undertaken field research on video art in Italy from the 1970s and 1980s, conducting interviews with artists, practitioners and scholars (all material is now available online at www.rewind.ac.uk).

Contact:

Laura Leuzzi, REWIND/talia, Visual Research Centre, Duncan of Jordanstone College of Art and Design, University of Dundee, Perth Road, DD1 4HT, Dundee, Scotland

E-mail: laura.leuzzi@gmail.com 
Notes

${ }^{1}$ There is a vast literature about the complex relationship between artists, visual art and television. It includes studies that examine the presence of artists on television, art documentaries/programmes and artists' contribution to programmes. Among the most relevant, updated and comprehensive volumes, relevant for this article, we can mention: Walker (1993), Bolla and Cardini (1994), Gazzano (1994, 2012), Di Marino and Nicoli (2001), Celant (2008), Senaldi (2009) and Partridge (2012).

${ }^{2}$ REWINDItalia is an Arts and Humanities Research (AHRC)-funded research project, led by Professor Stephen Partridge (DJCAD, University of Dundee). The project started in 2011 aims to explore the histories and narratives of video art activity in Italy between 1968 and 1994.

3 The Television Manifesto of Spatial Movement was also signed by: Anton Giulio Ambrosini, Alberto Burri, Roberto Crippa, Mario De Luigi, Bruno De Toffoli, Gianni Dova, Enrico Donati, Lucio Fontana, Giancarlo Carozzi, Virgilio Guidi, Beniamino Joppolo, Guido La Regina, Milena Milani, Berto Morucchio, Cesare Peverelli, Tancredi, Vinicio Vianello.

${ }^{4}$ This English translation of the Manifesto is available at http://www.medienkunstnetz.de/source-text/70/.

${ }^{5}$ For an overview of Sasso' works see Sasso (2003) and Filonzi (2008).

${ }^{6}$ Unless otherwise indicated, all translations from the original (e.g. Italian) are mine.

${ }^{7}$ For a comprehensive view of the evolution of his practice see Filonzi (2008). 
8 This RAISat channel, founded in 1990, must be not confused with the RAISat S.P.A, a company founded by RAI in 1997 and closed in 2010 to create satellite channels, including RAISat Art, a channel dedicated to Art.

${ }^{9}$ Private communication.

${ }^{10}$ Carosello was an advertising show made of sketch films, aired on Rete 1 from 1957 to 1977.

${ }^{11}$ Intermezzo was a programme, created in 1962 and broadcasted on the Second Channel after 9 o' clock Telegiornale.

${ }^{12}$ Unfortunately no footage has survived but a transcription of the last episode with Cage was published in Cage et al. (1978: 51-55). Few images published by the newspaper $L a$ Stampa, between January and February 1959, provided with captions in English are available on http://johncagetrust.blogspot.it/2011/04/lascia-o-raddoppia-milan-1959.html and http://johncage.org/blog/transcriptionTranslation.html, accessed 29 December 2013. ${ }^{13}$ Television Interventions is a project produced by Fields and Frame Productions, run by Stephen Partridge and Jane Rigby, for Channel 4 in 1990, which included nineteen works by artists for television (including a piece by Partridge himself, David Hall, Bruce McLean, David Cunningham and Ian Breakwell). These artworks were created to intervene during the normal broadcast, without introduction or presentation. The project was inspired by David Hall's TV Interruptions (7 TV pieces) (1971) (Partridge 1990; Walker 1993: 123-124)

${ }^{14}$ Extract from Partridge's presentation Artists versus Television: Intervention versus Mediation, at the symposium REWINDItalia: Videoart in Italy 1968-1982 (Rome, Macro Museo d'arte Contemporanea Roma, 19-20 April 2012). 
${ }^{15}$ Servizio Programmi Sperimentali was made up of a small group of experts guided by Mario Raimondo and Italo Moscati that developed research studies on various topics such as television series, experimental broadcast and video recording.

${ }^{16}$ The Prix Italia is a prize for quality television, held in Italy and organized by RAI, that involves all the public and private television services in the world. The XXX edition in 1978 was accompanied by the conference entitled Le arti visuali e il ruolo della televisione/The Visual Arts and the role of TV held on 12 and 13 September 1978 and organized by Alvise Zorzi, then Secretary General of Prix Italia. The event saw the participation of Douglas Davis, Gillo Dorfles, Luca Maria Patella, Vittorio Fagone and many more. The proceedings were published in RAI/Prix Italia 1979.

17 Gianni Toti e le disperimentazioni in RAI. Intervista di Anna Barenghi, http://lacasatotiana.blogspot.ch/2011_07_01_archive.html. Accessed 15 November 2013.

${ }^{18}$ A lost film, shot in 1918 by Nikandr Turkin, with script by Majakovskij. The few survived cuts were given by Lili Brik to Toti, who translated the title of the movie into Italian as Incatenata alla pellicola/Chained by the Film. 